This article was downloaded by: [University of Sussex Library]

On: 26 March 2015, At: 19:20

Publisher: Routledge

Informa Ltd Registered in England and Wales Registered Number: 1072954

Registered office: Mortimer House, 37-41 Mortimer Street, London W1T

3J H, UK

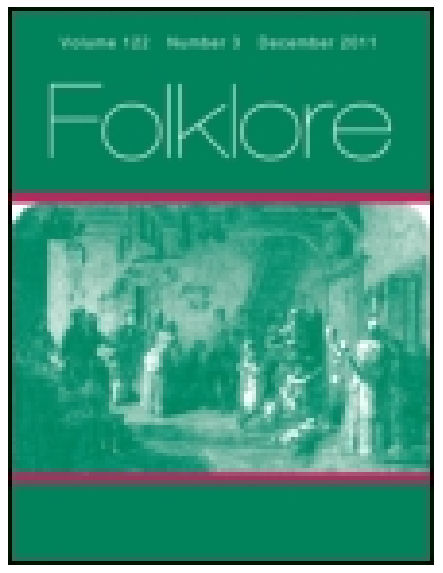

\title{
Folklore
}

Publication details, including instructions for authors and subscription information:

http:// www. tandfonline.com/loi/ rfol20

\section{The Sister's Son in Samoa}

\author{
A. C. Stanley ${ }^{a}$ \\ ${ }^{a}$ Rome \\ Published online: 06 Feb 2012.
}

To cite this article: A. C. Stanley (1902) The Sister's Son in Samoa, Folklore, 13:1, 75-76, DOI: 10.1080/0015587X.1902.9719665

To link to this article: http:// dx. doi. org/ 10.1080/0015587X.1902.9719665

\section{PLEASE SCROLL DOWN FOR ARTICLE}

Taylor \& Francis makes every effort to ensure the accuracy of all the information (the "Content") contained in the publications on our platform. However, Taylor \& Francis, our agents, and our licensors make no representations or warranties whatsoever as to the accuracy, completeness, or suitability for any purpose of the Content. Any opinions and views expressed in this publication are the opinions and views of the authors, and are not the views of or endorsed by Taylor \& Francis. The accuracy of the Content should not be relied upon and should be independently verified with primary sources of information. Taylor and Francis shall not be liable for any losses, actions, claims, proceedings, demands, costs, expenses, damages, and other liabilities whatsoever or howsoever caused arising directly or indirectly in connection with, in relation to or arising out of the use of the Content.

This article may be used for research, teaching, and private study purposes. Any substantial or systematic reproduction, redistribution, reselling, loan, sub-licensing, systematic supply, or distribution in any form to anyone is 
expressly forbidden. Terms $\&$ Conditions of access and use can be found at http://www.tandfonline.com/page/terms-and-conditions 
"A laxative.-' Sheep-pearls,' i.e. the droppings of sheep dissolved in water and drunk. My informant has seen mothers administer this dose to their children. Near Lochlomond," (MS. note by the late Dr. Gregor.)

"Tricklings [trik-linz], sb. sheep's dung-Pulverbatch. It was formerly-before the age of vaccination-a popular belief that 'ship's tricklin's,' duly administered, would cure the small-pox. 'Bessy, yo' mind as Granny dunna putt ship's tricklin's i' my yarbtay. I canna tak' it if 'er does-nod if I'm marked ever so.'" G. F. Jackson, Shropshire Word-Book, p. 453, s.v.

I hope to deal with the information given in the second Bluebook in a future number.

Alice B. Gomme.

\section{Tiz Sister's SON in SAMOA.}

\section{(Communicated by Mr. Andrezu Lang.)}

When I was at Apia in Samoa with Commodore Goodenough in the Pearl, in 1873 , I met the American Consul, who had married a Samoan, and who told me the following story of a custom called Vasu which prevailed in the islands as regards the rights of a nephew to his uncle's property.

There was a chief called "Bullamacow," who came to sec his uncle and admired very much a bread-fruit house ${ }^{1}$ he had just put up. The uncle said it had cost him a great deal, in fact nearly ruined him. Bullanacow said he thought it would look well in his "square." The uncle then said, "Pray, don't say that." However Bullamacow would not change his mind. All this meant that the uncle was to give Bullamacow his house, which he did not quite see.

So the nephew goes away disappointed. But a few days after this someone comes to the uncle's house, and says to one of the children, "Where is your mother?" and he answers, "Bullamacow has taken her away," as is the custom in these cases. The uncle

' A house for the storage of bread-fruit. 
bears it for a few days, but at last, longing to have his wife home again, makes up his mind to give up the house. This, however, is not enough now; he must take a present as well. So he trudges off with some baked pigs. When he arrives at his nephew's, Bullamacow says to him, "Why did you take the trouble to come all this way? I was just going to take your wife down to you to-morrow, but, however, as you have come, you will be able to stay here and take her back then yourself." Then when he sees the pigs he says, "How very unnecessary it was for you to bring these things."

However, he allows himself to be persuaded, and accepts the present. Now the uncle has to do the rest of the business, and it has to be done with delicacy. So he says, "Now, how do you think the bread-fruit house would look in that place? I think it would suit well; " and so the matter is settled. Next day the uncle takes his wife home, and a few days later Bullamacow comes down and carries off the bread-fruit house. So the poor uncle is ruined.

In the same way, if a nephew takes a fancy to a gun of his uncle's, he comes and takes it. Should the uncle naturally object to part with it, the nephew goes home and tells his mother, who says it will be all right: she will arrange matters. So she pronounces a curse upon the other family, saying the children shall die of elephantiasis. This so works upon their fears that they are ready to give anything up. It is to be noted that only the children of the eldest sister have the privilege of Vasu.

The Consul said that during the fighting, men used often to bring guns to his house to hide them from their nephews; and sometimes they have slept with guns lashed to their legs; but the nephews have come and taken them away even then.

I give this account from a journal kept at at the time.
A. C. Stanley.

Rome, 4th December, rgor. 